\title{
Humanizing Pedagogy: Minimizing Negative Teacher Talking Time on the Teaching of English Language as a Foreign Language
}

\author{
Dr. Ayman Hamad Elneil Hamdan Dr. Elsadig Ali Elsadig Elandeef \\ King Khalid University - College of Sciences \& Arts- Dhahran Aljanoub, KSA.
}

The authors extend their appreciation to the Deanship of Scientific Research at King Khalid University for funding this work through General Research Project under grant number (project number: 71 lyear: 2021)

Abstract

The study aims at studying minimizing negative teacher talking time as a tool of humanizing teaching English language as foreign language in Saudi Arabia context. The study accentuates the variety conceptual perspective of teaching talking time and its main causes. The study is based on quasi-experiment method and 50 students were divided into two groups; one group taught through minimizing teacher talking time and maximizing student teacher talking time interactively, whereas, the other group is taught deductively. The study found out that minimizing teacher talking time and maximizing student's time talking time enhance humanization sense of learning English language among Saudi learners and it promotes interactive motivational sense among the learners. The experimental group students' outcomes revealed positive gains through maximizing student talking time and positive interactive English practice in English classroom. This study is one of the forerunner studies which play a salient role in shed lighting on the importance of humanizing teaching English in Saudi Arabia context through minimizing teacher talking time. The study recommends that teaching English language should be based on learner centeredness relying on minimizing negative teacher talking time and maximizing student talking time through using pedagogic techniques and strategies.

Keywords: Teacher talking time, negative teacher talking time, positive teacher talking time efficiency, humanization .

DOI: $10.7176 / J L L L / 77-07$

Publication date:March $31^{\text {st }} 2021$

\subsection{Introduction}

Teaching English language as a foreign language requires various pedagogical aspects entailing teacher talking time and humanization. Teacher Talking Time (TTT) serves a major source of comprehensible target language input and away of creating interaction and engagement (Cook, V., 2000). Lots of voices grow up demanding minimizing teacher talking time in the classroom though TTT may not always be counterproductive. English teachers need to talk in the classroom in various forms such as contextual personated presentation, questioning, concept checking, instruction checking, initiation of natural conversation with students, warmer or ice breaking and managerial interactive purposes (Hedge, 2000). None the less, negative talking time such as unnecessary talk functions as counterproductive aspect in learning a foreign language (Lightbrown, P. M., \& Spada, N. (2013). Humanization process is based on humanistic learning theory which is based on the development of selfactualization, student centered and the teacher's role is that of a facilitator. The humanistic theory in education stresses that human beings are inherently good, and that basic needs are vital to human behaviors. It engages social skills, feelings, intellect, artistic skills, practical skills, and more as part of their education.

Recent studies have highlighted the significance of humanizing teaching English language as a foreign language through minimizing negative teacher talking in the context of Saudi Arabia. Additionally, the study highlights the crucial role of maximizing student talking time in promoting learners' proficiency particularly speaking skill. It is argued that teacher talking time dehumanizes learners due to tackling them as an object from critical pedagogy perspective. Furthermore, negative teacher talking time can be regarded as a means of destruction of constructive consciousness and critical thinking (Hedge, 2000). Many researchers conducted studies on the impact of teacher talking time and using deductive approach which is based on teacher centeredness on learning English properly. However, most of the studies' findings focus on minimizing teacher talking time and maximizing teacher talking time as a technique of promoting pedagogy (Freeman, 2011). This study aims to bridge the gap through investigating how minimizing negative teacher talking humanizes learning English language as a foreign language in Saudi Arabia context.

\subsection{Research objectives}

This study aims at accomplishing the following objectives:

-to investigate the significance of minimizing negative teacher talking time in English class and the implications of humanizing teaching English in Saudi Arabia context;

-to explore how minimizing negative teacher talking time enhances interactivity and learner centeredness in English class; and 
-to examine the impact of minimizing negative teacher talking time in English class on motivating learners and promoting positive attitudes towards learning English.

\subsection{Research questions}

To meet the stated objectives, the following research questions were raised:

-To what extent does minimizing negative teacher talking time in English class enhance learners' positive attitudes towards learning English?

-How does minimizing negative teacher talking time in English class humanize learning and teaching English language?

- How far does minimizing negative teacher talking time enhance interactivity and learner centeredness in English class?

\subsection{Review of Literature}

The theoretical framework adopted in this study is that humanistic theory focusing on the human freedom, dignity, and potential. A central assumption of humanism, according to Huitt (2001), is that people act with intentionality and values. A primary purpose of humanism could be described as the development of self-actualization. In humanism, learning is student centered and personalized, and the educator's role is that of a facilitator. Affective and cognitive needs are key, and the goal is to develop self-actualized people in a cooperative, supportive environment (DeCarvalho 1991). The humanistic theory of learning involves the concept of learning through watching the behavior of others and what results from that behavior. However, learning does not have to involve a behavior change (Barrett, 2006).

\subsection{Definition of Teacher Talking Time (TTT)}

Long man dictionary of language teaching and applied linguistics defines TTT as variety of language sometimes used by teachers when they are in the process of teaching. Rod Ellis (1985) has formulated his own view about teacher talking time: Teacher talking time (TTT)is the special language that the teacher uses when addressing L2 learners in the classroom. It is composed of systematic simplification of the formal properties of teacher language. According to Li Ming(1998), TTT is a special simplified code with double features. Nunan, D (1991 ) defines TTT as the amount and type of talking that teacher do and he shows that teachers should pay attention to the amount of talk in the light of their pedagogical objectives.

\subsection{Types of TTT}

TTT can be divided into positive and negative TTT. Negative TTT should be minimized in the classroom.

\subsubsection{Negative Teacher Talking Time Criteria}

The first criterion is ${ }^{1}$ unnecessary talk referring to the teacher tendency toward deviated talk that lacks purpose, pedagogical and linguistics aspect. For instance, teacher tends to talk about themselves proudly.

The second one is echoing which refers to unnecessary repetition of students' talk or responses. This purposeless repetition make students feel that they responses are not perfect, so it shakes their performance confidence.

The third one is the breaking the students' silence when posing problems or asking questions or when waiting student to participate in the lesson stages. Teachers should give their students enough time to think as a silence period.

The fourth criterion refers to the teacher provides learners with information that they can discover by themselves such as grammar, meanings of vocabulary items and corrections

\subsection{Causes of Negative TTT}

-TTT is caused by various causes such as lack of experience so a novice teacher

1-As teachers, we should be able to maximize students' opportunities to talk in class to help them develop their speaking skills in English. They must be given lots of chances to communicate, with as little teacher intervention as possible. Whenever a student can say something, the teacher must not intervene or interfere by talking. No one, neither the teacher nor any student, should monopolize talking time in class. It is important to let our students know that their contributions are valuable and welcome. We need to give them the feeling of being in charge of their learning by having them share the job with us.

proposes he or she uses the best pedagogical method and students are actually. learning well.

- lack of confidence which embodies some teachers' fear of silence because they propose that silence means students are no learning

- long unnecessary explanation not using elicitation

- asking lots of follow up questions

-a teacher might paraphrase or summarize information instead of giving the students an opportunity to infer the information. 


\subsection{Positive TTT Criteria}

Krashen (1987) proved that learners need a silent period before they become able to speak. This silent period assists learner develop competence in the target language and process language before being able to produce it.

- TTT supplies comprehensible in put in low anxiety environment and it also provides language model especially when the learners do not live in English speaking country.

- TTT plays a positive role in learning English as a foreign or second language in the light of language exposure. -TTT plays a seminal role in deductive approach particularly in presentation and controlled practice in PPP.

-Positive TTT is necessary to provide language model in listening activities and teacher may indulge in spontaneous speech with the students. It also tunes language input to assist comprehensible in put in personalized contextual presentation, question and natural conversation.

\subsection{Minimizing Negative TTT Techniques and Increasing STT}

The best ways of learning languages include autonomous learning, more learners' practice and discovery learning. Negative ${ }^{1}$ TTT blocks and limits the amount of students' talking time because it results loss of concentration and boredom among learners.

Many ${ }^{1}$ techniques can assist minimize TTT in the classroom such as:

-Tolerating students' silence expression

- Using dialogic teaching approach

-Cooperative work

--project method, tolerating students' silence and using body language

-Using realia, body language and using lots of teaching aids

-Using of technology and using elicitation technique rather than explanation

-Using game based learning or gamification.

- Use group work or pair work: Instead of engaging in dialogue with students themselves, you can divide the class into pairs and have them practice conversations. Groups can work together on writing assignments or to develop speeches or make videos all while speaking English to each other. In these scenarios, you can provide oversight and support without dominating the class conversation

- Ask students to read and explain the instructions: Letting students read the instructions aloud and explain them to the class can provide a great way for you to give your voice a rest while centering the student. And since the words are written down, it feels a lot safer and easier for the learner to get started with English.

- Avoid excessive expressions: Probably the most difficult technique to implement is just to stop talking after giving the initial instruction or explanation. Teachers who can curb their own voice after a single explanation will see a lot of reward in increased student attention and interaction.

-Activities to Increase Student Talk Time and Engagement: Role plays ( Examples: Job interviews, part-child discussions, squabbles between neighbors or visits to the doctor can make great role plays), Imitate Socrates (Socrates pretended to know nothing, peppering his students with brain-twisting questions that got them thinking. You can get your ESL students started having a discussion among themselves about a powerful question.), Do not be afraid of quiet ( Sometimes students feel reluctant to participate and so a great silence descends on the classroom. As a teacher, you may feel like you need to fill that silence with your own voice, but you don't. Just wait until one of the students gets so uncomfortable with the silence that they are willing to risk talking.), and Spark mini debates (Depending on your context, you may not want to introduce controversial topics. Still, nothing gets people talking quite so eagerly as a good debate. Some debate topics for your classroom could include whether children should provide support for aging parents or high school students should wear uniforms).

-Using genius hour approach and task based learning

\subsection{Achieving the Right Balance of TTT and STT}

A language teacher must design her/his lessons to make participation of all most all the students in a classroom so his/her lesson plan has to include a certain percentage for teacher talk time (TTT) and student talk time (STT) to teach each skill. In a learner centered classroom, TTT must not exceed the expected specified percentage. Allwright (1982) said that teachers who 'work' too much in the classroom were not teaching successfully. He mentioned that a good language teacher is able to 'get students to do more work in the classroom. Nunan, (1999) indicated that continuous teacher talk during the lessons did not develop students' listening comprehension and communication skills. Nunan (2003) proves the earlier fact, mentioning that "Research has repeatedly demonstrated that teachers do approximately 50 to 80 percent of the talking in classrooms." As far as a learner centered classroom concerned, to practice the target language Student Talk Time (STT) be supposed to be around $80 \%$ during the course of the lesson (Nunan, 1991). Consequently, it is needed to incorporate the learner centered approach into the existing curricula in all disciplines not only in the international level but also in local context. In 
a foreign or second language classroom, for instance a teacher introduces a new lesson even to make it more learner centered classroom teacher can give students the choice of selecting what they are going to learn) such as talking about the daily routine.

Nilton (2011) accepts that though he practices 60 to 80 percentages or 40 to 60 percentages of teacher talk time (TTT) respectively, for elementary and intermediate levels when he teaches oral communication, these figures are beyond the adequate level TTT. If there is more talk by the teacher, students become passive and their involvement in the classroom participation would be very less. This is what was experienced in the traditional chalk and talk method. Students' use of the language must be further promoted for a high range of qualitative thought once they become capable to respond/ communicate in simple necessary discussions. They have to be able to communicate, critically observe, analyze, and practice with the new language in a successful learning environment. Much research on TTT has focused on its quantity (amount) and/or quality (effectiveness). These studies have provided new insights into the ways EFL/ESL teachers teach in the classroom. Harmer (2012) and Nunan (2003); among them this research highlights Ur's interaction patterns such as group work, pair work, individual work, closed-ended teacher questioning (IRF) open-ended teacher questioning, choral responses, collaboration, student initiates teacher answers, full- class interaction and self-access. Further knee to knee conversation, face to face variation, tiny talks, show and tell the inventors' seminar, twenty questions, picture cards, acting from a script, play-scripts, acting out dialogues, communication games, prepared talk, questionnaires, roleplay and Carol's quick quest are some other practices (Harmer, 2012).

\subsection{Humanistic Learning Theory}

Humanism is a pedagogical approach that believes learning is viewed as a personal act to fulfill one's potential. Humanism focuses on the individual as the subject and asserts that learning is a natural process that helps a person reach self-actualization. Scenarios and role modeling are important factors in humanistic learning, as are experiences, exploring and observing others. Humanism, a paradigm that emerged in the 1960s, focuses on the human freedom, dignity, and potential. A central assumption of humanism, according to Huitt (2001), is that people act with intentionality and values. This is in contrast to the behaviorist notion of operant conditioning which argues that all behavior is the result of the application of consequences and the cognitive psychologist belief that the discovering knowledge or constructing meaning is central to learning. Humanism rejected was the assumption that learners were easily controlled by rewards and punishments. Humanists thought this behaviorist approach of rewards and punishments failed to see that humans are complex thinkers. So, humanists emerged largely as a reaction to

1-Some effective ways of reducing teacher talking time and boosting students' involvement at the same time are, for example, letting the students re-explain the lesson to each other, letting them paraphrase ideas and instructions, summarize previous lessons at the beginning of class and ask follow-up questions, letting them do the conclusion, encouraging them to bring materials to the classroom, to provide feedback to each other and to report something to the class. Letting them reflect on their performance will enhance their learning and help them to improve their language skills. Furthermore, give the students time to read and explain the instructions and the teacher asks open-ended questions instead of yes Ino questions.

the negativity and simplicity of behaviorist beliefs about childhood (Tomlinson, 2008). Humanists also believe that it is necessary to study the person as a whole, especially as an individual grows and develops over the lifespan. It follows that the study of the self, motivation, and goals are areas of particular interest. A primary purpose of humanism could be described as the development of self-actualization. In humanism, learning is student centered and personalized, and the educator's role is that of a facilitator. Affective and cognitive needs are key, and the goal is to develop self-actualized people in a cooperative, supportive environment Hedge, 2000). The humanistic theory of learning involves the concept of learning through watching the behavior of others and what results from that behavior. However, learning does not have to involve a behavior change. Learning comes about as a result of observation (Barrett, 2006).

The ${ }^{1}$ humanistic theory in education stresses that human beings are inherently good, and that basic needs are vital to human behaviors. It states that the student is the authority on how they learn, and that all of their needs should be met in order for them to learn well. For example, a student who is hungry won't have as much attention to give to learning. The humanistic theory approach engages social skills, feelings, intellect, artistic skills, practical skills, and more as part of their education. Self-esteem, goals, and full autonomy are key learning elements in the humanistic learning theory. It is very closely related to constructivism and it directly focuses on the idea of selfactualization which is at the top of the hierarchy of needs (Duchesne and McMaugh,2016).Teachers can create classroom environments that help students get closer to their self-actualization and they fulfill students' emotional and physical needs, giving them a safe and comfortable place to learn, plenty of food, and the support they need to succeed. This kind of environment is the most conducive to helping students learn. Maslow and the humanists believed

1-Humanistic approach is a perspective that emphasizes looking at the whole person, and the uniqueness of each 
individual. Humanistic approach begins with the existential assumptions that people have free will and are motivated to achieve their potential and self-actualize. It emphasizes the personal worth of the individual, the centrality of human values, and the creative, active nature of human beings. The approach is optimistic and focuses on the noble human capacity to overcome hardship, pain and despair.

that behaviorism and other psychology theories had a negative perception of learners, for example operant conditioning in behaviorism psychology suggested that students only acted in a good or bad manner because of the reward or punishment and could be trained based on that desire for a reward. Maslow and humanistic psychology suggests that students are inherently good and will make good decisions when all their needs are met..focuse on the idea that Learners bring out the best in themselves, and that humans are driven by their feelings more than rewards and punishments (Veugelers, 2011). Khatib and Hamidi (2013) contend that humans are driven by feelings causes educators who understand humanistic psychology to focus on the underlying human, emotional issues when they see bad behavior, not to just punish the bad behavior. The humanistic learning theory developed further and harnesses the idea that if students are upset, sad, or distressed, they are less likely to be able to focus on learning. This encourages teachers to create a classroom environment that helps students feel comfortable and safe so they can focus on their learning. Emotions are at the center of humanism psychology (Wong, 2014). ${ }^{1}$ Humanistic approaches to learning are based on the principles of humanism and are founded most notably on the work of Abraham Maslow (1908-1970) and Carl Rogers (1902-1987).

They center on the learner as an individual and consider that learning is not just about the intellect, but also about educating the whole person taking a person's interests, goals, and

Humanism is grounded in the belief that people are innately good. This type of psychology holds that morality, ethical values, and good intentions are the driving forces of behavior, while adverse social or psychological experiences can be attributed to deviations from natural tendencies. Humanism incorporates a variety of therapeutic techniques, including Rogerian (person-centered) therapy, and often emphasizes a goal of selfactualization. Humanism arose in the late 1950s as a "third force" in psychology, primarily in response to what some psychologists viewed as significant limitations in the behaviorist and psychoanalytic schools of thought. Behaviorism was often criticized for lacking focus on human consciousness and personality and for being deterministic, mechanistic, and over-reliant on animal studies. Psychoanalysis was rejected for its strong emphasis on unconscious and instinctive forces and for being deterministic, as well. In 1957 and 1958, Abraham Maslow and Clark Moustakas met with psychologists who shared their goal of establishing a professional association that emphasized a more positive and humanistic approach. The discussions revolved around the topics they believed would become the core tenets of this new approach to psychology: Self-actualization, creativity, health, individuality, intrinsic nature, self, being, becoming, and meaning. After receiving sponsorship from Brandeis University, The American Association for Humanistic Psychology was founded in 1961.

enthusiasm into account, so that full potential can be achieved. This approach to learning is student centered, with learners encouraged to take responsibility for their own learning and being intrinsically, rather than extrinsically motivated. The primary goal of a humanistic education is human well-being, including the primacy of human values, the development of human potential, and the acknowledgment of human dignity (Duchesne and McMaugh, 2016). A humanistic approach implies a central concern for sustainable human and social development, in which the fundamental purpose of education should be to sustain and enhance the dignity, capacity and welfare of the human person in relation to others and to nature. The major focus of a humanistic approach is the development of the whole student with an emphasis on emotional aspects of the student. The learning concentrates upon the development of the student's self-concept. If the student feels good about him or herself then that is a positive start. Feeling good about yourself involves an understanding of your talents, strengths and weaknesses, and a belief in your ability to improve.

\subsection{The Principles of Humanistic Learning Theory}

A humanistic approach to education and development is based on the foundation of an integrated approach to knowledge, learning and development. Some core principles are important: respect for life and human dignity; equal rights and social justice; respect for cultural diversity, as well as a sense of shared responsibility and a commitment to international solidarity. These principles are all fundamental aspects of our common humanity. Schunk, (2012) states that there are several important ${ }^{1}$ principles involved in the humanistic learning theory that all lead to self-actualization:

-Humanistic learning is student-centered, so students are encouraged to take control over their education. They make choices that can range from daily activities to future goals. Students are encouraged to focus on a specific subject area of interest for a reasonable amount of time that they choose. Teachers who utilize humanistic learning believe that it's crucial for students to find motivation and engagement in their learning, and that is more likely to happen when students are choosing to learn about something that they really want to know.

-Humanistic teachers believe that knowledge and feelings go hand-in-hand in the learning process. Cognitive and affective learning are both important to humanistic learning. Lessons and activities should focus on the whole 
student and their intellect and feelings, not one or the other.

-A safe learning environment because humanistic learning focuses on the entire student, humanistic educators understand that they need to create a safe environment so students can have as many as their needs met as possible. They need to feel safe physically, mentally, and emotionally in order to be able to focus on learning. So humanistic educators are passionate about the idea of helping students meet as many of their needs as possible.

-Actualizing Tendency: According to Rogers, we all have a tendency to strive toward personal growth. We all have ambitions to be better. Rogers called this an 'actualizing tendency', and used this concept to underpin his ideas about education.

-Freedom to learn: Rogers write the book Freedom to Learn which outlines how it is important for students to be freed from the constraints of a school curriculum in order that they can be free to explore things they are interested in -Unconditional positive regard: We have already seen from Maslow that humanists believe students need to have strong self-esteem (positive regard for themselves). Rogers believes that we can help students achieve stronger self-esteem by unconditionally seeing students in a positive light. Much like a parent who loves their child unconditionally, teachers have to see that their students are fundamentally good, even when they're at their worst. -Facilitation: Because humanists don't believe there should be a set curriculum or learning outcomes, teachers become facilitators rather than authority figures. Teachers encourage students to seek new knowledge and provide the materials and support needed. This approach is very similar to the approach used in constructivist and sociocultural education. Their job is to foster an engaging environment for the students and ask inquiry-based questions that promote meaningful learning.

-Intrinsic motivation: Rogers believes schools have historically repressed intrinsic motivation that we all had before we went to school.

-Encourage Inquiry Learning: When students have chosen a topic to learn about, give them rich resources and an inquiry-based learning environment so students can explore their interests without having them stifled by nasty worksheet printouts!

-Choice and control: The humanistic approach places a great deal of emphasis on students' choice and control over the course of their education. Students are encouraged to make choices that range from day-to-day activities to periodically setting future life goals. This allows for students to focus on a specific subject of interest for any amount of time they choose, within reason. Humanistic teachers believe it is important for students to be motivated and engaged in the material they are learning.

\section{1-The five basic principles of humanistic education can be summarized as follows: \\ 1) Students' learning should be self-directed. \\ 2) Schools should produce students who want and know how to learn. \\ 3) The only form of meaningful evaluation is self-evaluation. \\ 4) Feelings, as well as knowledge, are important in the learning process. \\ 5) Students learn best in a nonthreatening environment.}

-Felt concerns: Humanistic education tends to focus on the felt concerns and interests of the students intertwining with the intellect. It is believed that the overall mood and feeling of the students can either hinder or foster the process of learning.

-The whole person: Humanistic educators believe that both feelings and knowledge are important to the learning process. Unlike traditional educators, humanistic teachers do not separate the cognitive and affective domains. This aspect also relates to the curriculum in the sense that lessons and activities provide focus on various aspects of the student and not just rote memorization through note taking and lecturing.

-Self-evaluation: Humanistic educators believe that grades are irrelevant and that only self-evaluation is meaningful. Grading encourages students to work for a grade and not for intrinsic satisfaction. Humanistic educators disagree with routine testing because they teach students rote memorization as opposed to meaningful learning. They also believe testing doesn't provide sufficient educational feedback to the teacher. Humanistic language teaching is an approach based on the principle that the whole being, emotional and social, needs to be engaged in learning, not just the mind. Within the humanistic approach, education is about creating a need within the student, or cooperate with the student his self-motivation. Humanism is about rewarding yourself. Intrinsic rewards are rewards from within oneself, rather like a satisfaction of a need (Zucca, 2010).

\subsection{The Role of Teacher in Humanistic Learning Theory}

In the humanistic learning theory, teachers and students have specific roles for success. The overall ${ }^{1}$ role of a teacher is to be a facilitator and role model. The teacher's role, according to the humanistic theory, is to be a role model. The teacher is to model appropriate behavior and make an effort not to replicate inappropriate behavior. A teacher is also expected to provide a reason and motivation for each task, teach general learning skills, foster group work, and if possible, given a choice of tasks to the students (Huitt, 2001). 
Zucca(2010) states that in the classroom, teaching and learning can effectively take place if the entire atmosphere is aptly humanized by the teacher. In essence, to humanize the classroom therefore implies to impart desirable human qualities, values, attitudes and interests to the learners with a view to making them acquire worthwhile affective qualities of human beings. This can only result from a healthy interaction between the teacher and his/her students, which in turn would engender effective learning. Teaching process is only meaningful and desirable when there is a warm and cordial interaction and relationship between the teacher and his/her students (Emeh and Enukoha, 1994); a relationship that recognises and respects the personality of both the teacher and the learners. The teacher in this case is instrumental to how students react in the classroom: how they react to the subject matter, and how they perceive the teacher and his teaching methods (Omoguere, 2000). In short, all interactions in the classroom should have the stamp of humanism and pragmatism.

Ray and Smith (2010) stated that the teacher's role includes:

-Teaching learning skills: Good teachers in humanistic learning theory focus on helping students develop learning skills. Students are responsible for learning choices, so helping them understand the best ways to learn is a key to their success.

-Providing motivation for classroom tasks: Humanistic learning focuses on engagement, so teachers need to provide motivation and exciting activities to help students feel engaged about learning.

-Providing choices to students in task/subject selection: Choice is central to humanistic learning, so teachers have a role in helping work with students to make choices about what to learn. They may offer options, help students evaluate what they're excited about, and more.

-Creating opportunities for group work with peers: As a facilitator in the classroom, teachers create group opportunities to help students explore, observe, and self-evaluate.

-Teachers can help students set learning goals at the beginning of the year, and then help design pathways for students to reach their goals. Students are in charge of their learning, and teachers can help steer them in the right direction.

-Teachers can create exciting and engaging learning opportunities. For example, teachers trying to help students understand government can allow students to create their own government in the classroom. Students will be excited about learning, as well as be in-charge of how everything runs.

-Teachers can create a safe learning environment for students by having snacks, encouraging students to use the bathroom and get water, and creating good relationships with students so they will trust speaking to their teacher if there is an issue.

-Teachers can utilize journaling to help students focus on self-evaluation and their feelings as part of learning. Using prompt questions can help students better understand their feelings and progress in learning.

The teacher assumes the role of a coach or facilitator to assist the student in establishing and using their learning strategy to achieve their goal. Doing this means the teacher must be aware of the student's unique needs, to be effective at supporting the student in acquiring the desired knowledge. By understanding the student's unique needs, the teacher can assist in designing the strategy to support the individual student's intellectual and emotional development. Creating a non-threatening and supportive environment is important to this development(Ray and Smith,2010).

\subsubsection{Teacher of English as a Humanizer}

Arifi (2017) states a distinction between romantic, pragmatic and rhetorical views toward humanism. Romantic humanists often claim that by touching the students' emotions and invoking their inner selves, they will encourage more successful language learning. According to this view, people learn language better if they have a meaningful experience. What is ironical is that romantic humanist educators often claim to be concerned with the whole person, while systematically excluding so many aspects of human life.

Accordingly, Russon, (20030), outlined the key concerns of the humanistic approaches as:

-Respect for learners as people.

-Respect for the learners' knowledge and independence.

-Recognize the affective (i.e. emotional) as well as cognitive nature of the learning experience.

-Recognize the role of self-discovery and of the individual learner's autonomy and independence.

-Teach in an enabling way, regarding teachers as enablers or facilitators who assist learners in their self-discovery rather than as instructors who 'transmit' knowledge to learner.

Accordingly, in Gomes's approach to having a peaceful communication, four principles are outlined: love your communicative neighbor implying that every human being, as use of language communicate caringly, compassionately, cordially); dignify your daily dialogue; prioritize positivizers in your language use (e.g. dignity is practiced by employing words that convey positive meanings); and be a communicator humanizer (i.e. communicating in a humanized way that is inspired by the ideals of dignity, human rights, peace, justice and equality( Tomlinson, 2008).

Teacher of English as a ${ }^{1}$ humanizer as a professional who shares a belief in such fundamental values as human rights, justice, peace, and dignity and who applies them in his/her teaching of English, as well as outside the 
classroom. Humanizing is a powerful socio-communicative force available to human beings.

Frias, (2019) enumerates a list for self-check of English teacher as a humanizer:

-View and apply English Language Teaching as a system for helping learners grow as individuals and as members of communities, both inside and across cultures.

-View and apply assessment of learners' performance in a positive way, by emphasizing their strengths in using English as a means of interaction.

-View and treat the students as persons who have both communicative rights and responsibilities.

-Create peace-building-enhancing-promoting activities so that learners can communicate as caring and compassionate users of English, that is, as appliers of what I call 'communicative peace'.

-Use inspiring literature which exemplifies humanization through dialogue (between/among fictional characters). Such applications could be extended to performing arts such as the theater, cinema, TV dramatization (serials).

-Use examples of humanizing illustrative sentences from learners' dictionaries and stress the importance of such dignifying uses of English.

-Prepare learners to make humanizing uses of the internet, through chatting with English-language-using e-friends. The creation of humanizing phraseologies for use on the Web could become a project for groups in different EFL contexts.

-Within copyright law restrictions, adapt and/or change materials so that they can contribute to personal and to interpersonal humanization. The use of positivizers (for instance, adjectives enhancing positive human qualities, traits) could be systematized in the learning of humanizing vocabulary( Zimmerman, 2010).

\subsection{The Role of the Learner in Humanistic Learning Theory}

Ideally, learning should be an active process, where the student is engaged with the learning activities to acquire the knowledge specific to their situation. Since a major theme is the learner being the source of authority, the learner determines what learning materials are used, and how they will learn the material. They could choose to read, listen to speech, watch movies or practice what they have learned through social interactions or by producing a specific output (Schneider, Bugental, \& Pierson, 2001).

The term "humanizing" is derived from both the adjective "humane" and the noun "human". The derivation from the noun "human", simply implies belonging to or concerning human beings - people (man, woman, child) especially as opposed to animals and inanimate objects. On the other hand, the adjective "humane" implies treating people or animals in a way that is not cruel and inflicts like pains and suffering on them. To humanize a situation means to treat such a situation as if it were a human being, and not as if it were a thing or an object that has no feelings or thoughts. In other words, to humanize in this context implies to accord human attributes to all things whether or not they deserve them. In other words, this evokes the feeling of humaneness, i.e., a feeling tinged with compassion, sympathy, empathy and consideration for others. Humanization in the classroom context, therefore, is a process of giving human attributes and values such as honor, respect, love, dignity, friendship, etc., to other people: their social status, age, and level of education notwithstanding. This approach is anchored on the theory of humanism, which is a system of beliefs concerned with the needs of people, and the restoration of the universally acceptable human values.

The learner also establishes the quantity of learning, as in how much do helshe needs to learn about a specific subject. But making the correct or incorrect choice in their learning decisions rests on the student and not the teacher. This reinforces the student as the source of authority (Crain, 2015).

\subsection{Pillars of Humanism}

A humanist educator's teaching strategy will have four philosophical pillars. These pillars will guide the teacher's beliefs and, ultimately, how they teach. These four pillars are: Free Will: We have free choice to do and think what we want; Emotions impact Learning: We need to be in a positive emotional state to achieve our best; Intrinsic Motivation: We generally have an internal desire to become our best selves; Innate Goodness: Humans are good at the core (Bendeck,2013).

\subsection{Humanizing Language Curriculum Development}

Lefrancois ( 1991) states that most humanistic approaches to education share a number of common emphases. Chief among them is greater attention to thinking and feeling than to the acquisition of knowledge. A second common emphasis is on development of notions of self and individual identity. The third major emphasis is on communication.A final emphasis shared by most humanistic approaches is the recognition and development of personal values. Carl Rogers (1982) suggested that significant learning only take place when the subject matter is perceived to be of personal relevance to the learner and when it involves active participation by the learner. He 
further explains that the learning which is self-initiated and which involves feelings as well as cognition is the most likely to be lasting and pervasive. According to Stevick (1980, 1990), to ${ }^{1}$ humanize English Language Teaching (ELT), language teachers should (1) create a sense of belonging, (2) make the subject relevant to the learner, that is, to personalize language learning (3) involve the whole person,

1-Stevick (1980) explores how humanistic methods, particularly the Silent Way and Counseling Learning, are realized in the language classroom. Stevick cited in Willam and Burden (1997) saw a need for a humanistic approach to language teaching as a response to what he saw as alienations which were accountable for failure in modern language teaching: alienation of learners from materials, from themselves, from the class and from the teacher. Stevick (1980) recommends that teachers take a serious attention to what goes on inside and between their students. He emphasized that teachers must be attuned to the needs and wants of the learner. He further explains that teacher should enable students to reconcile their performing self and their critical self to provide a harmony between them. This entails paving the ways for students to be engaged in the activities of the classroom. (4) encourage a knowledge of the self, (5) develop personal identity, (6) minimize criticism, (7) encourage selfinitiation, self -evaluation and creativity, (8) allow for choice. In order to help language teachers apply the abovementioned features in his/her teaching, teachers and curriculum developers should develop curriculum and materials which are line with humanistic language teaching. According to Curtis (1971), humanists believe that the function of curriculum is to provide each learner with intrinsically rewarding experience that contribute to personal development. He continued to say that humanizing curriculum should stress the need to personalize education, emphasis must be placed on the needs and interests of individuals, and curricula must be constructed to enable students to actualize their own potentialities. Gay (2002) states that if teachers see the purpose of school as transformative, they must develop the expertise needed to facilitate the inclusion of personal and culturally relevant experiences in the classroom and seek out those that provide opportunities to scaffold and support instruction . He goes on to say that when life experiences are ignored, dismissed, or devalued, students infer that their personal perspectives and world views are nonessential to their learning experiences. This can be increased when teachers shift to a standardized curriculum while following an externally dictated timeline which has no relation to the students experiences.

Nunan (1988, p. 23) assert, in seeking to develop a learner-centered curriculum, the curriculum developer should: (1) recognize the wealth of experiences, resources and cultural capital that learners bring to the learning session; (2) take account of the diverse backgrounds of the learners and consider this within any planning of the learning program; (3) tailor resources and activities to make them relevant and useful to the learners. Materials generated by learners can be used, as can authentic resources which will mirror the activities/practices that are related to real life language use; (4) provide learning resources and activities which interest and challenge the learners; (5) ensure learning activities provide opportunities for real-life language use by mirroring real communication; (6) involve learners in negotiating and creating the learning program. Learners can be involved in selecting topics and texts and determining the content and pace of learning. Nunan (1988) states that "one way of typifying curriculum models is the degree to which they allow curriculum development to occur at the local level" (21). To him, a fully centralized curriculum which is devised in a centralized location and then disseminated to a wide range of learning institutions does not take the local factors into account. In fact; he favors de-centralized curricula or school-based curricula which are designed wholly or in part within the teaching institution itself and tries to take learners' preferences and experiences into account.

Most of these scholars stress the need to help learners to personalize, localize and make meaningful their experience of the target language, as well as the need for materials to be affectively engaging and cater for all learning style preferences. Tomlinson (2003) argues that "language teaching materials need to be humanizing, taking into account learners' 'experience of life, their interests and enthusiasms, their views, attitudes and feelings and, above all, their capacity to make meaningful connections in their minds".Tomlinson $(2003,2006,2013)$ proposed eight ways for developing course book which are more humanistic by (1) writing in large and varied team, (2) using a text-driven approach, (3) using a multi-dimensional approach which is based on principles that using affect, mental imagery and inner speech is what we do during effective and durable learning, (4) taking to the learners by chatting to the learners casually in the same way that good teachers do and trying to achieve personal contact with them by revealing their own preferences, interests and opinions, (5)using literature, (6) varying the unit focus, (7) connecting to the learners' views and opinions, (8) providing text-free generalizable activities which can be used with texts selected by the learner from a resource pack of materials, from library, from the internet or from their own resource, including awareness activities. On the whole, as Tomlinson (2013) says, "the aim of humanizing materials is to develop materials which are locally relevant and which engage the learners personally in both local and global. According to Hansen (2011), a fruitful approach to humanistic curriculum includes focusing on the physical and emotional needs of the learners and attempting to design learning experiences that will help fulfill these needs. He continued to say that curriculum objectives and activities should match emotional issues that are salient at particular stages of learners' life and humanistic curriculum should respond to the learners' 
concern about the meaning of life. Curtis (1971) stated that a humanistic curriculum demands an emotional relationship between students and teacher. The teacher must provide warmth and nurture emotion while continuing to function as a resource center. He or she should present materials and create challenging situations to facilitate learning. Tomlinson (2013) is optimistic about the future of humanistic materials by hoping materials developers to develop (1) more personalized and localized materials; (2) more respect for the learners' intelligence, experience and communicative competence; (3) more affectively engaging content; (4) more opportunities for learners with experiential and especially kinesthetic learning style preferences; (5) more attempts to engage the learner in the language learning process as an experienced, intelligent and interesting individual ; (6) more attempts to use multidimensional approaches to language learning.

\subsection{Methodology \\ 4.1 Study Design}

A quantitative study design is used for examining the impact of minimizing negative teacher talking time as humanizing on enhancing learning English proficiency in Saudi Arabia context. The quasi -experiment method is used for two group -controlled and experimental group.

\subsection{Study participants}

The study involves 50 students studying English as an intensive course at King Khalid University and they were randomly selected. They are divided into two groups as control group and one experimental group. The experimental group was taught by minimizing negative teacher talking and maximizing student talking time through using inductive approach which is based on learner centeredness. Whereas, the control group were taught by implementing deductive approach based on conventional teacher talking time. Both groups have been taught for sixteen weeks. All participants signed an agreement that they gave informed consent to participate in this study and were aware that they could stop participating at any time. Then, the participants were assessed with a pre-test. The pre-test scores were used as a covariate to adjust for the initial difference in language level proficiency in particular speaking skill.

\subsection{Study variables}

The independent variable included in this study was minimizing negative teacher talking in English classroom. Whereas, the dependent variable included in this study entails humanizing teaching English language as a foreign language.

\subsection{Study Instrument}

The speaking test was conducted to describe the learners' self-confidence and self-actualization in producing English through written text and spoken discourse. This includes the mean score of the students and individual scores following the implementation of minimizing negative teacher talking time. The test was a proficiency test composing of written and spoken section where students are asked to present a presentation in individualistic selected topic.

\subsubsection{Instrument validity and reliability}

The instrument used for measuring the learners' language proficiency in particular speaking skill was determined for its validity and reliability. The test was devised by the researchers, which was then reviewed and validated by a panel comprised of five professors who major in ELT and test measurement. The changes in the test were made based on the recommendations of the professors. The reliability of the test was ensured through the retest/test procedure. Initially, a pilot test was conducted on a sample of ten students who did not participated in the study. Pearson correlation was used to achieve a value of 0.88 . The post-test results were also evaluated, which provided a value of 0.86 for the Pearson correlation, which indicates high reliability for both the tests.

\subsection{Study administration}

Each group was taught 160 hours using separated skills syllabus based on academic corpus and European Framework. An observational checklist was used for evaluating the involvement of the students and their productive skills. A presentation, speaking and essay writing tests were also conducted for evaluating the productive skills in both pre-test and post-test. The pre-test and post-test aimed to measure the students 'English language proficiency in productive skills focusing on self-efficacy, self-confidence, interactivity, cogent language production with cohesion and coherence consideration, accuracy and fluency.

4.5.1Pre-test

The research instruments of this study were a pre-test and a post-test. Both tests aimed at assessing Saudi EFL students' English language productivity with self-confidence. The two researchers designed the pre-test. It was given to both experimental and control groups before starting the experiment. It consists of an essay and speaking 
questions scored out of ten. Both the essay test and speaking test were scored out of five marks. The 50 students were asked to present a presentation on particular topic. After that, they were asked to do the tests. The pre-test was corrected by one of the professors majoring in ELT.

\subsubsection{Post-test}

The pre- and post-tests were validated by a panel of five professors majoring in ELT and test measurement from King Jazan University. The professors' feedback, comments and recommendations were taken into consideration. The post-test was given to both groups and they were given the same amount of time and instructions to complete the test. The post-test was corrected by one of the professors majoring in ELT.

\subsection{Data analysis}

The tests were administered twice, before and after the experiment, to assess the performance of Saudi students' language proficiency and self-efficacy. Statistical Package for Social Sciences was used for computing the collected data. A t-test was applied for assessing the difference between the two groups of learners.

\subsubsection{Results}

The pretest was administered to all study participants to control for any initial differences between the experimental and control groups. A t-test for independent samples was used to compare the mean scores of Saudi students in the two groups on the pre-test using SPSS.

Table (1) shows the difference between the mean scores of the experiment and control groups on the pre-test.

\begin{tabular}{|l|l|l|l|l|l|l|}
\hline Test & Group & Number & Mean & Std. dev. & T-test & Sig \\
\hline Pretest & Control & 25 & 4.39 & 3.37 & 3.18 & 0.01 \\
\hline & Experiment & 25 & $2 . .25$ & 2.18 & - & $\begin{array}{l}\text { Not } \\
\text { significant }\end{array}$ \\
\hline
\end{tabular}

\section{Table (1) Pre-test scores}

It can be seen from Table 1 that no significant differences were found between the mean scores of Saudi students of both groups on the pre-test. It shows that both the experimental and the control groups were equivalent in their performance on the test before the implementation of minimizing negative teacher talking time in teaching English language .

To reveal the differences between the two groups attributed to the implementation of minimizing negative teacher talking time in English class, the proficiency test was administered as a post-test. A t-test for independent samples was then used to compare the mean scores of the two groups on the post-test.

Table (2) shows the difference between the mean scores of the experiment and control groups on the Post-test.

\begin{tabular}{|l|l|l|l|l|l|l|}
\hline Test & Group & Number & Mean & Std. dev. & T-test & Sig \\
\hline Post-test & Control & 25 & 20.29 & 5.43 & 7.20 & 0.00 \\
\hline & Experimental & 25 & 26.65 & 4.11 & 0.05 & - \\
\hline
\end{tabular}

\section{Table (2) Post-test result}

Table (2) shows the results of the t-test for the mean gain of the experimental and control groups on the posttest. As can be seen from Table 2, the t-values was significant at the 0.05 level for the total test scores, a result that indicates the existence of statistically significant differences between the two groups on the post-test that is attributed to the experimental group. Saudi students' performance in the test in this group scored higher than the students in the control group at p-value 0.05 , which shows the benefit of implementing minimizing negative teacher talking time in English class to enhance self-efficacy and self-confidence in producing English language.

\subsection{Discussion}

From the above results, it is noticed that minimizing negative teacher talking time in English class room helps Saudi learners promote their English language proficiency in terms of language productivity and it enhances selfconfidence in communicating in English in spoken or written form. The researcher thinks that minimizing teacher talking time helps the learners construct self-confidence, self-efficacy and active interactivity which goes with Arifi's (2017) findings by highlighting that humanizing teaching English through constructing self-confidence ,self-efficacy, self-actualization and active interactivity enhance motivation among learners and facilitate productive interactivity in terms of speaking and writing skill. Furthermore, learners can feel ease in daring to produce English without sense of scaring of making mistakes due to the tolerant atmosphere. It is also noticed that implementation of minimization of TTT and humanizing English class lead to more interactivity, participation and engagement. This result indicates that the problem is very clear for the teachers, researchers and syllabus designers but it appears that the implementation of minimization of TTT and humanizing English class require special pedagogical training entailing the techniques and strategies of minimizing negative teacher talking time in English class. Moreover, declarative knowledge, procedural knowledge and strategies for humanizing English class should be mastered properly throughout training sessions. The study score reveals that minimizing negative teacher talking time is effective because it builds self confidence among learners, keeps them engaged in the tolerant interactive atmosphere and constructs the feeling of class belonging. The study is in line with the study 
of Brush\& Saye (2010), which found that minimizing negative teacher talking time in English class allows students to engage, interact, voice their opinions, produce English language spontaneously and feel relaxed in the intimate amicable atmosphere based on mutual opinion exchange with sense of mutual respect and appreciation. Similarly, research by Brodie (2002) concluded that learner centered teaching motivates learner's interactivity and enhances learning process through mechanical and repetitive drill in terms of vivid practice. Moreover, it makes learner be an integral part of language discourse in English class and focal component of creating classroom discourse and spoken language vivacity in English language. DeCarvalho,(1991) stated that maximizing student talking time in English class fosters the procedural knowledge of learning English language among learners and builds a self confidence among learners in English class. Hence, this leads to humanization of education by tackling learners as subject rather than to deal them and object in regard to critical pedagogy and Freirean pedagogy which attempt to help the oppressed fight back to regain their lost humanity and achieve full humanization in education instead of banking education which is based on depositing knowledge to learners who becomes just like a container. The results of the present study matches Tomlinson (2008) findings which demonstrated that humanizing teaching English language involves activation of active interactive in English class through stimulating the students' participation and practice English language in the class room through excessive speaking amount of English language corresponding with limitation of the teacher's role as a facilitator, imitator or feed backer. The findings of this study accentuates that minimizing negative teacher talking time in English class enhances humanization of teaching and learning English through constructing much time for the students to practice English confidently and voice their opinions trustfully in a tolerant relaxing social environment. Hence, learners' motivation is raised and safety feeling in English class is maintained among learners.

To sum up, the researcher states the findings as the following:

-Minimizing negative teacher talking time in English can class enhance learners' positive attitudes towards learning English.

-Minimizing negative teacher talking time in English class humanizes learning and teaching English language because students feel relaxed and safe when making mistakes. In addition, students' engagement and participation increase positively and courageously.

- Minimizing negative teacher talking time enhances interactivity and learner centeredness in English class .In addition; it creates balance of class discourse and inculcates sense of belonging.

- Minimizing negative teacher talking time leads to activate dialogic approach and it provides students with great chance to spell their ideas.

\subsection{Conclusion}

Education has an important and strategic role to ensure the development of cognitive intelligence, psychomotor and affective. Education aims to develop human potential and forms a good personality. However, current education loses humane aspects (dehumanization). This is due to the approach used for teaching based on the teacher center and not centered on student center. The ultimate purpose of humanistic approach in education is the learning process that was started and is intended for the benefit of humanizing mankind. Humanizing humans is to achieve self-actualization. The implication of humanistic approach in education is how t to encourage students to think critically and act according to the values of humanity. Since then, the humanistic approach in education should be applied in the process of learning and teaching in order to produce a good learner and critical of reality. Minimizing negative teacher talking time and maximizing student talking time can be implemented in English class as a tool of humanization.

\section{Pedagogical Implications}

The positive side of minimizing teacher talking time in English class embodied in humanizing teaching and learning English from various psychological and social aspects. Thus, it is important to English teacher make their classroom discourse productive through minimizing negative teacher talking time by using pedagogic strategies or techniques and maximizing students talking time through open dialogue, discussion, conversation, indirect tolerant feedback, mutuality of respect, equal balance of taking turn in classroom talk, constructing self-efficacy in students and creating safe social environment which is based on humanistic harmony. The study implies that Saudi learners are highly motivated to learn English but they are scared of making mistakes among their colleagues and teacher. Hence, creating safe classroom setting based on humanizing teaching helps Saudi students overcome the problem of scaring and feeling shy. As the result, they feel relaxed and a social part of the group with equal sense of humanization based on self-confidence and self-efficacy. Therefore, the study recommends that minimizing negative teacher talking time as a tool of humanizing pedagogy should be implemented in Saudi English class setting at lower level and higher level in order to inculcate confidence among students. In addition, teaching English should be based on inductive pedagogic approach based on learner centeredness in order to activate critical thinking and creative thinking; in addition, to construct self-actualization and capability of voicing opinions and generating ideas trustfully. The study recommends that teaching English in the context of Saudi 
Arabia should be based on learner centeredness, minimizing negative teacher talking time through using pedagogic strategies and techniques, maximizing student talking time, creating tolerant and safe educational environment based on humanization ,and respected dialogue and discussion should be set in English classroom. Suggested future works will entail investigating maximization of student talking time in English class as a tool for coping with 21th century skills and reshaping the profession of teachers to be more humanized in terms of pedagogy. Hence, the studies will view teachers from various multiple roles such as model, facilitator, collaborator, leader, dialogue initiator, risk taker, parent and educator. Furthermore, suggested future works will entail dialogic approach as a core sense of minimizing teacher talking time and proper functionalization of teachers' role to maximize the participative role of the students in humane atmospheric classroom embedding activation of high order thinking and construction of productive thinking composing of critical thinking and creative thinking.

\section{Acknowledgements}

Special appreciation is due to King Khalid University administration for encouraging us to conduct such researches.In addition, I would like to express my deepest gratitude to all people who helped me conduct this research. . My gratitude goes to the participants who participated in this study. Most importantly, I would like to thank English Centre at KKU.

\section{References}

Alderson, J .C (1992) . Evaluating Second Languages Education. Cambridge. Cambridge University Press.

Arifi, Q. (2017). Humanistic Approach in Teaching Foreign Language (from the Teacher Perspective). European Scientific Journal. Prishtina.

Bendeck Sotillos, S. (Ed.). (2013). Psychology and the Perennial Philosophy: Studies in Comparative Religion. Bloomington, IN: World Wisdom. ISBN 978-1-936597-20-8.

Brodie, K. et al. (2002). Forms and substance in learner-centred teaching: Teachers' take-up from an in-service programme in South Africa. Teaching and Teacher Education, 18, 541-559.

Brush, T. \& Saye, J. (2010), "Implementation and Evaluation of Student Centered Learning Unit: A Case Study", Thomas Brush - Arizona \& John Saye - Auburn University, Running Head. Educational Technology Research and Development, Vol. 48, No. 3

Chaudron. C(1988)Second Language Classrooms: Research on Teaching and Learning . Cambridge. Cambridge University Press.

Curtis, T. B.( 1971). What is a humanizing curriculum. Paper presented at American association of school administrators annual convention, New Jersey, February 20-24. Retrieved from http://files.eric.ed.gov/?id=ED050464

Crain, W. (2015). Theories of Development: Concepts and Applications: Concepts and Applications. London: Routledge.

DeCarvalho, R. (1991). The humanistic paradigm in education. The Humanistic Psychologist, 19(1), 88-104.

Dornyei, Z. (2001). Motivational strategies in the language classroom. Cambridge: Cambridge University Press.

Duchesne, S. \& McMaugh, A. (2016). Educational Psychology for Learning and Teaching. Melbourne: Cengage Learning.

Dwyer, S. (2006), "The English Teacher as Facilitator and Authority” TESL-EJ, Volume 9, Number 4March 200.

Ellis, R. (1999). Making the classroom acquisition-rich. In R. Ellis (Ed.), Learning a second language through interaction (pp. 211-229). Amsterdam: John Benjamins.

Freeman, D. Larsen (2011), “Techniques and Principles in Language Teaching”,2011, with M. Anderson. Third Edition. Oxford: Oxford University Press.

Frias, J. (2019). Improving learning experiences by using Humanism and Constructivism teaching approaches in the classroom. Philosophy of Education. T\&L cert. John Wiley and Sons 1(1), 1-5.

Gay, G. (2002). Preparing for culturally responsive teaching. Journal of Teacher Education, 53, 106-116.

Hansen, G. H. (2011). Lozanov and the teaching text. In B. Tomlinson (Ed.), Materials development in language teaching (403-414). London: Continuum.

Harmer, J. (2008), The Practice of English Language Teaching, 4th Edition - Person Longman.

Hedge, T. (2000), "Teaching and Learning in the Classroom.” Oxford University Press.

Huitt, W. (2001). Humanism and open education. Educational Psychology Interactive. Valdosta, GA: Valdosta State University. Retrieved September 11, 2007, from the URL: http://chiron.valdosta.edu/whuitt/col/affsys/humed.html.

Khatib, M., Sarem, S. N., \& Hamidi, H. (2013). Humanistic Education: Concerns, Implications and Applications. Journal of Language Teaching \& Research, 4(1), pp. $45-51$

Lefrancois, G. L. (1991). Psychology for teaching. New York. Wadsworth.

Lynch, B (1996). Language Program Evaluation: Theory and Practice . Cambridge. Cambridge University Press. Nilton, H. (2011). Teacher Talking Time in the EFL Classroom. Retrieved on 20, May,2013 from 
http://www.scielo.org.co/scielo.php?script=sci_arttext\&pid=S1657- 07902005000100009

Norris, J., \& Ortega, L. (2000). Effectiveness of L2 instruction: A research synthesis and quantitative metaanalysis. Language Learning, 50, 417-528.

Ray, K., \& Smith, M. C. (2010). The kindergarten child: What teachers and administrators need to know to promote academic success in all children. Early Childhood Education Journal, 38(1), 5-18. https://doi.org/10.1107/s10623-010-0383-3

Nunan, D. (1989). Designing tasks for the communicative classroom. Cambridge: Cambridge University Press.

Nunan, D. (1991). Language teaching methodology: A textbook for teachers. Hemel Hempstead: Prentice Hall International.

Nunan, D. (1999). Second Language Teaching and Learning. Heinle and Heinle. Nunan, D. (2003). Practical English Language Teaching. McGraw-Hill. Rutherford, W.E. (1987). Second language grammar: Learning and teaching. New York: Longman.

Ur,P. (2005). A Course in Language Teaching. India: Cambridge University Press. View publication stats

Rogers, C. (1982). Freedom to learn. Ohio. Charles Merrill.

Russon, John Edward (2003). Human Experience: Philosophy, Neurosis, and the Elements of Everyday Life (pbk. ed.). State University of New York Press.

Schneider, K., Bugental, J. F. T., \& Pierson, J. F. (2001). The handbook of humanistic psychology: Leading edges in theory, research, and practice. London: SAGE

Stevick, E. (1980). Teaching languages. A way and ways. Rowley: Newbury House.

Stevick, E. (1990). Humanism in language teaching. Oxford: OUP.

Stoll Lillard, A. (2005). Montessori: The science behind the genius. New York/Oxford: Oxford University Press. Thomas, A.M(1987). Class Interaction. Oxford: Oxford University Press.

Tomlinson, B. (2008). Humanising an EAP Textbook. Humanising Language Teaching. Year 10; Issue 2. Year 10; Issue 2; April 2008, ISSN 1755-9715.

Tomlinson, B.( 2012). Materials development for language learning and teaching. Language Teaching, 45(2), 1 37. doi:10.1017/S0261444811000528

-Wong, P. T. P. (2014). Humanistic theories. Retrieved from http://www.drpaulwong.com/humanistic-theories

Zimmerman, E. (2010). Creativity and art education: A personal journey in four acts. Art Education, 63(5), 84-92

Zucca-Scott, L. (2010). Know thyself: The importance of humanism in education. International Education, 40(1), 31-38. 